\title{
Shrinking lung syndrome treated with rituximab in pediatric systemic lupus erythematosus: a case report and review of the literature
}

\author{
Chelsea DeCoste* ${ }^{*}$, Dimas Mateos-Corral and Bianca Lang
}

\begin{abstract}
Background: Shrinking lung syndrome (SLS), a rare complication of systemic lupus erythematosus (SLE) characterized by dyspnea, low lung volumes, and a restrictive pattern on pulmonary function tests (PFTs), has only been reported in a few children. Given the rarity of SLS there is a paucity of literature regarding its optimal treatment. Outcomes are variable, with case reports documenting some improvement in most patients treated with corticosteroids, with or without additional immunosuppressive agents. However, most reported patients did not recover normal lung function. We report full recovery of a child with SLE and SLS following treatment with rituximab and review the current literature.

Case presentation: An 11-year-old boy presented with a malar rash, myositis, arthritis, oral ulcers, leukopenia, anemia, positive lupus autoantibodies and Class II nephritis. He was diagnosed with SLE and treated with corticosteroids, hydroxychloroquine, azathioprine, and subsequently mycophenolate with symptom resolution. At age 14, his SLE flared coincident with a viral chest infection. He presented with a malar rash, polyarthritis, increased proteinuria and pleuritis which all improved with corticosteroids and ongoing treatment with mycophenolate. Six weeks later he presented with severe dyspnea, markedly decreased lung volumes, but otherwise normal chest X-ray (CXR) and high-resolution chest computed tomography (HRCT). He was found to have severely restricted PFTs (FEV1 27\%, FVC 29\%; TLC 43\%). After additional investigations including echocardiography, pulmonary $C T$ angiography, and diaphragmatic fluoroscopy, he was diagnosed with SLS and treated with rituximab and methylprednisolone. At 1 month his symptoms had improved, but he still had dyspnea with exertion and severely restricted PFTs. At 6 months his FVC and TLC had improved to 51 and $57 \%$ respectively, and were 83 and $94 \%$ respectively at 4 years. He had returned to all baseline activities, including competitive hockey.
\end{abstract}

Conclusions: Although extremely rare, it is important to recognize SLS as a possible cause of dyspnea and chest pain in a child with SLE. Optimal treatment strategies are unknown. This is the second reported case of a child treated with rituximab for SLS who recovered normal lung function. International lupus registries should carefully document the occurrence, treatment and outcome of patients with SLS to help determine the optimal treatment for this rare complication.

Keywords: Rituximab, SLE, Lupus, Child, Lung

\footnotetext{
* Correspondence: chelsea.decoste@sickkids.ca

Department of Pediatrics, IWK Health Centre and Dalhousie University, 5850/

5980 University Avenue, PO Box 9700, Halifax, Nova Scotia B3K 6R8, Canada
}

(c) The Author(s). 2021 Open Access This article is licensed under a Creative Commons Attribution 4.0 International License, which permits use, sharing, adaptation, distribution and reproduction in any medium or format, as long as you give appropriate credit to the original author(s) and the source, provide a link to the Creative Commons licence, and indicate if changes were made. The images or other third party material in this article are included in the article's Creative Commons licence, unless indicated otherwise in a credit line to the material. If material is not included in the article's Creative Commons licence and your intended use is not permitted by statutory regulation or exceeds the permitted use, you will need to obtain permission directly from the copyright holder. To view a copy of this licence, visit http://creativecommons.org/licenses/by/4.0/. The Creative Commons Public Domain Dedication waiver (http://creativecommons.org/publicdomain/zero/1.0/) applies to the data made available in this article, unless otherwise stated in a credit line to the data. 


\section{Background}

Shrinking lung syndrome (SLS) is a rare complication of systemic lupus erythematosus (SLE) characterized by decreased lung volumes and a restrictive pattern on pulmonary function testing (PFTs). Patients typically present with progressive dyspnea and chest pain [1-3]. The diagnosis may be delayed, particularly in pediatric patients, because of failure to consider or recognize this disorder. The exact pathophysiology is unknown [1-3].

Given the rarity of SLS there is a paucity of literature regarding optimal treatment. Case reports and series have documented improvement in most patients treated with corticosteroids, with or without immunosuppressive agents. However, the majority of patients have an incomplete recovery $[4,5]$. Recently, rituximab, a monoclonal antibody directed against the CD20 antigen found on the surface of B lymphocytes, has been used successfully in several adult patients and one child with SLE complicated by SLS $[6,7]$. We report a child with SLE who developed SLS at age 14 and recovered fully following treatment with rituximab. We also review the literature on SLS in pediatric patients to increase awareness of this exceptionally rare complication, as well as review outcome of patients previously reported with SLS who were treated with rituximab.

\section{Case presentation}

At age 11 years, our patient was diagnosed with SLE after presenting with a malar rash, oral ulcers, polyarthritis, myositis, and anemia. His past history was remarkable only for mild asthma; family history was positive for maternal asthma and hypothyroidism. Work-up revealed leukopenia (WBC 2.5 10e9/L), hypocomplementemia (C3 $0.23 \mathrm{~g} / \mathrm{L}$ ), positive anti-nuclear antibody, anti-dsDNA (633 IU/ml; normal less than 10$)$, anti-SSa/Ro, and anti-Smith antibodies, Class II lupus nephritis and a SLEDAI of 29. A baseline chest radiograph (CXR) was normal. He was treated with prednisone, hydroxychloroquine (HCQ), and azathioprine. A year later he had no symptoms of his SLE but was evaluated for an exercise-associated cough that was felt to be due to his asthma. A CXR was normal, PFTs showed moderate obstruction and symptoms resolved with a bronchodilator. Over the next few months, despite ongoing $\mathrm{HCQ}$, azathioprine and low dose prednisone he had recurrence of malar rash and mild arthritis; a repeat renal biopsy showed Class III b lupus nephritis and azathioprine was replaced by mycophenolate mofetil (MMF) which was increased up to $700 \mathrm{mg} / \mathrm{m} 2 /$ dose BID, and subsequently decreased due to gastrointestinal side effects. This resulted in resolution of all symptoms but some ongoing nephritis (SLEDAI 12).

At age 14 he was admitted to his local hospital with fever, pleuritic chest pain, dyspnea, and cough. Bilateral pleural effusions were seen on CXR and he was given empiric antibiotics for possible pneumonia prior to transfer to our center, where he received a 3-day pulse of intravenous methylprednisolone (IVMP) for a suspected SLE flare (C3 0.70; anti dsDNA 95; SLEDAI 29). His chest symptoms resolved completely and respiratory syncytial virus (RSV) infection was subsequently confirmed by PCR and was thought to have triggered the flare. One month later, despite treatment with low dose prednisone and MMF $(535 \mathrm{mg} / \mathrm{m} 2 /$ dose BID, although compliance was questionable), his SLE again flared. He presented with a malar rash, polyarthritis, as well as findings of pleuritis manifesting with chest pain, dyspnea, and a left pleural effusion. He was treated with pulse IVMP followed by increased MMF $(625 \mathrm{mg} / \mathrm{m} 2 /$ dose BID) and daily oral prednisone $(1 \mathrm{mg} / \mathrm{kg} / \mathrm{d})$.

Six weeks later his rash and arthritis had improved, but he reported increasing shortness of breath with marked exercise intolerance. On examination he was afebrile, his heart rate was 120 , respiratory rate 40 , and oxygen saturation $95 \%$ in room air. He appeared dyspneic with difficulty speaking in full sentences. Chest examination revealed shallow breathing and decreased air entry bilaterally. Physical examination was otherwise unremarkable. Work up for infection was negative. His SLEDAI had decreased to 14, C3 had normalized (0.97) and anti dsDNA had decreased to 39. CXR and highresolution computed tomography (HRCT) showed severely reduced lung volumes with no pleural or interstitial disease; there was slight atelectasis but no other significant abnormalities (Figs. 1, 2). An echocardiogram was normal and a CT angiogram showed no evidence of pulmonary embolus. PFTs revealed a severe restrictive pattern with forced expiratory volume in $1 \mathrm{~s}$ (FEV1) of $27 \%$, forced vital capacity (FVC) $29 \%$, and total lung capacity (TLC) 43\% (Fig. 3). Fluoroscopy documented significantly reduced diaphragmatic movement. He was diagnosed with SLS, and because of worsening dyspnea despite recently increased immunosuppression, he was treated with IVMP $1 \mathrm{~g}$ daily for 3 days followed by rituximab $1 \mathrm{~g}$ ( 2 doses, 2 weeks apart). He was also referred to physiotherapy for pulmonary rehabilitation.

One month later he reported some improvement in physical endurance, though he still had dyspnea with mild exertion and PFTs remained severely restrictive. At 6 months, however, he reported much improved exercise tolerance with ability to play some hockey. His FEV1 and FVC had improved to 42 and 51\% respectively and TLC had increased to $57 \%$. A planned second course of rituximab, ( $1 \mathrm{~g}, 2$ doses, 2 weeks apart) was given at 6 months; preceding $\mathrm{B}$ cell counts were $8 \%$. He was tapered off corticosteroids over the next 9 months and continued on HCQ $(5 \mathrm{mg} / \mathrm{kg} / \mathrm{d})$ and MMF $(600 \mathrm{mg} / \mathrm{m} 2 /$ dose BID). Serial CXRs showed gradual lung volume 

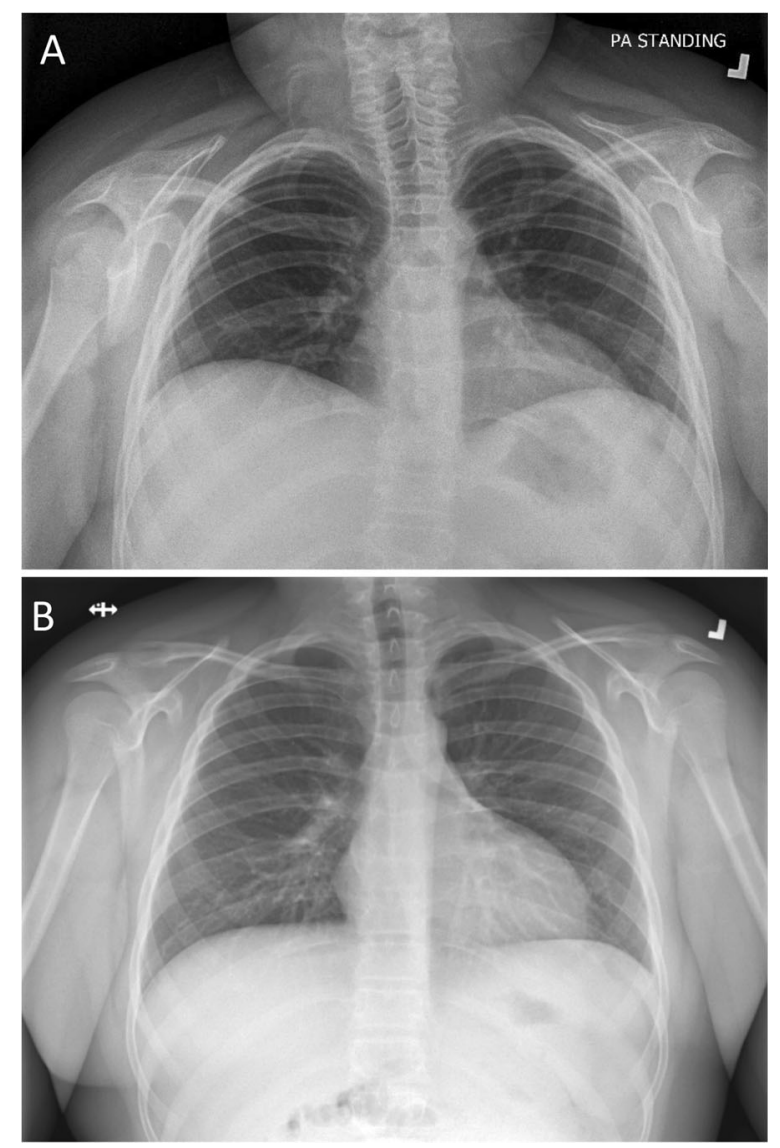

Fig. 1 a Chest X-ray at presentation with SLS, showing decreased lung volumes and raised hemidiaphragms $\mathbf{b}$ Normal chest $\mathbf{X}$-ray 3 years later

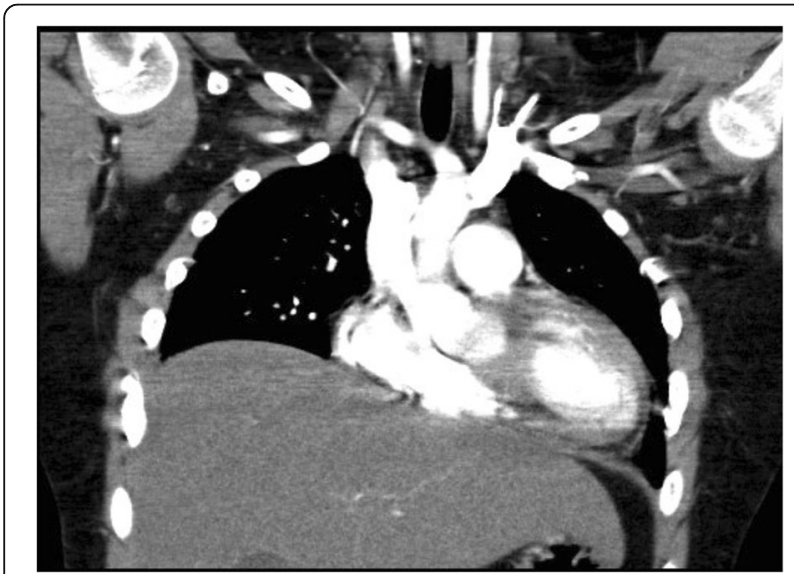

Fig. 2 High-resolution computed tomography (HRCT) of the chest at presentation with SLS, showing decreased lung volumes and slight atelectasis expansion. One year after his presentation he returned to playing competitive hockey, with no limitations and no respiratory symptoms. Four years later, he remained asymptomatic with no limitations in activity, no evidence of restrictive lung disease on PFTs (FVC 83\%, TLC 94\%), and a normal CXR. He remained on the same doses of HCQ and MMF with no clinical evidence of SLE disease activity, normal complement levels (C3 0.97), anti dsDNA 16, a SLEDAI of 2, and a follow renal biopsy showed no active nephritis.

\section{Discussion}

Shrinking lung syndrome is a rare complication of SLE with an incidence of approximately $1 \%$ in adult lupus patients $[1,5]$. The incidence in pediatric SLE is unknown, but is likely even less common. As such, the diagnosis of SLS may not be considered or recognized in a child with SLE. Clinical features include progressive dyspnea, exercise intolerance, and pleuritic chest pain, all of which were described by our patient. Physical examination frequently reveals tachypnea with decreased air entry and the use of accessory respiratory muscles but is otherwise unremarkable. Findings on CXR often include significantly reduced lung volumes with elevated hemidiaphragms and may include pleural effusions, basal atelectasis, and pleural thickening. HRCT typically shows no parenchymal lung disease, though it may be more sensitive than CXR in demonstrating pleural effusions and atelectasis $[4,8]$. PFTs show a restrictive pattern [4]. Reduced diaphragmatic excursion may be demonstrated on chest fluoroscopy, as was seen in our patient, or may be demonstrated using M-mode ultrasonography [8].

The pathogenesis of shrinking lung syndrome remains incompletely understood. When first described by Hoffbrand and Beck in 1965, the condition was thought to be due to surfactant deficiency causing microatelectasis [9]. Since then a number of mechanisms have been suggested, including phrenic nerve dysfunction, pleural inflammation and fibrosis, and diaphragmatic dysfunction due to myositis or neuropathy $[3,10]$. Anti-SSa/Ro antibody positivity has been associated with both SLS and myositis, and has been suggested to support the theory that myositis contributes to diaphragmatic dysfunction in some patients $[3,11]$. Of note, our patient was antiSSa/Ro positive and had myositis as part of his SLE course. The frequent occurrence of pleuritic chest pain in up to $80 \%$ of patients with SLS has led to a more recently proposed mechanism of pleuritic pain leading to reflex inhibition of diaphragmatic activation and subsequent dysfunction in at least a subset of patients with SLS $[1,3]$. Henderson et al. have proposed that pleural inflammation due to the underlying rheumatic disease may lead to activation of neural reflexes which inhibit deep inspiration and cause chronic lung hypoinflation. 


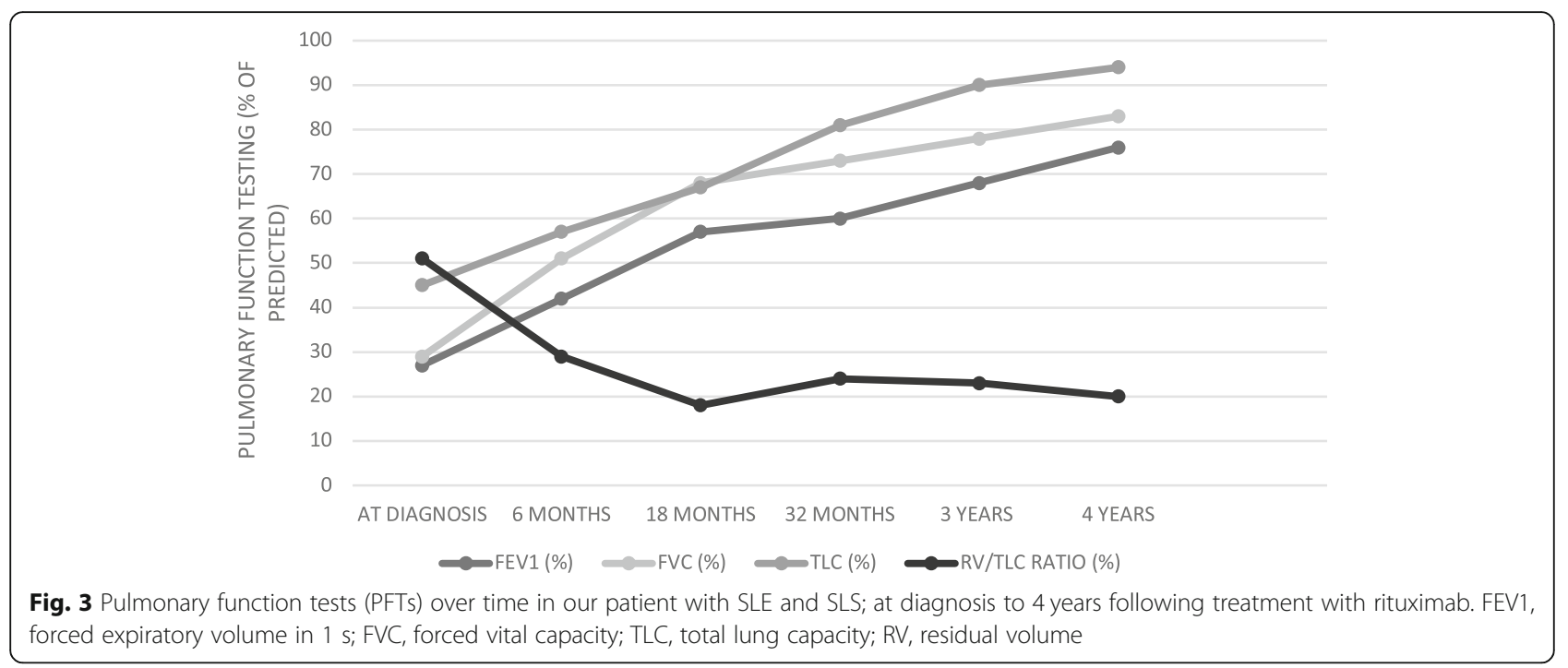

This is postulated to gradually reduce lung compliance and results in a positive feedback cycle [12]. Interestingly, our patient had developed pleuritic chest pain 2 months prior to his diagnosis of SLS, and had documented pleuritis associated with an RSV infection, and then associated with a flare of his SLE, which may have initiated the pathogenetic process leading to SLS.

There is no standard treatment for patients with SLS. Corticosteroids are the most frequently reported initial treatment of SLS, and can lead to full recovery in some patients $[3,5,11,13]$. Immunosuppressive agents including cyclophosphamide, azathioprine, and methotrexate are often given along with corticosteroids or if corticosteroids alone are ineffective. There are also a few reports of theophylline and beta-agonists used effectively in SLS, and others advocate the use of analgesia to combat chest pain and pulmonary rehabilitation to improve lung expansion $[1,3,5,12,13]$. Although rare fatal cases have been described, the prognosis of SLS in adults is generally considered to be good, particularly in comparison with the progressive course and significant mortality associated with fibrotic interstitial lung disease in patients with SLE [1]. Some clinical improvement has been reported in most patients with SLS, however, recent literature makes it clear that despite treatment many patients do not achieve full recovery. Langenskiold et al., in a review of 35 cases with documented pre and post treatment PFTs, found that only $20 \%$ of patients with SLS regained normal lung function [4]. Duron et al. reported full recovery in only a minority of patients in their review of 155 patients with SLS, with $42.9 \%$ of patients showing chronic and persistent hemidiaphragm elevation [1]. A report of 20 cases from a large single center in 2018 showed a similar outcome, with $86.7 \%$ of patients showing continued restrictive defects on spirometry despite improved lung volumes [5]. The lack of full recovery in both adult and pediatric patients with SLS has led to 15 reports of rituximab use in adults and 2 reports in children with SLS complicating SLE [1, 3, 4, 6-8, 12, 14-16] (Table 1). Normal PFTs were reported in one child treated with rituximab [7], however the other child did not respond [12]. All 4 adult patients with well-documented post-treatment PFTs had normal or near normal findings $[3,4,6]$. Although the degree of objective improvement was not documented in the remaining 11 adult cases treated with rituximab, all were reported to have improved or stabilized. (Table 1). There has also been a recent report of a 19-year-old male with pediatric-onset SLE who developed SLS refractory to IVMP and cyclophosphamide and had some improvement with belimumab, a monoclonal antibody directed against BLyS receptors on B-cells, though long-term follow-up is still ongoing [11].

Shrinking lung syndrome is extremely rare in pediatric lupus patients (defined as 16 years or less at diagnosis), with only 6 well-documented case reports identified in our literature review from 1984 to 2019 (Table 2). Age at onset of SLS ranged from 12 to 15 years, 5 were female, all presented with dyspnea, and 5 had associated chest pain. Interestingly, 3 of the 6 presented at the time of diagnosis of SLE, a much more frequent occurrence than that reported in adults with SLS. Of the 6 patients, only 2 reported a return to baseline respiratory function, both clinically and documented on PFTs [2, 7]. In addition to these 6 patients, our literature review identified 3 patients with pediatric onset SLE who developed SLS at age 19 or 20 [11, 19, 20]. Some improvement in lung function was documented in 2 of these patients, one treated with IVMP, cyclophosphamide and azathioprine, and 1 treated with belimumab. In addition, 7 SLE 
Table 1 Clinical features, treatment and outcome of patients with SLS associated with SLE who received treatment with rituximab

\begin{tabular}{|c|c|c|c|c|c|c|c|c|}
\hline Reference & Sex & $\begin{array}{l}\text { Age at } \\
\text { SLE } \\
\text { diagnosis }\end{array}$ & $\begin{array}{l}\text { Age at } \\
\text { SLS } \\
\text { diagnosis }\end{array}$ & $\begin{array}{l}\text { Clinical } \\
\text { presentation }\end{array}$ & $\begin{array}{l}\text { Imaging findings at } \\
\text { SLS diagnosis }\end{array}$ & $\begin{array}{l}\text { PFTs at SLS } \\
\text { diagnosis }\end{array}$ & Treatment & Outcome \\
\hline [1] & $\mathrm{F}$ & Unknown & 61 & $\begin{array}{l}\text { Chest pain, } \\
\text { history of } \\
\text { pleurisy, } \\
\text { dyspnea }\end{array}$ & $\begin{array}{l}\text { Elevated diaphragms, } \\
\text { atelectasis, pleural } \\
\text { thickening }\end{array}$ & $\begin{array}{l}\text { TLC } 46 \% \\
\text { DLCO 25\%, KCO 59\% }\end{array}$ & $\begin{array}{l}\text { CS + Beta-agonists + } \\
\text { RTX (dose } \\
\text { unknown) + } \\
\text { Physiotherapy }\end{array}$ & Improvement \\
\hline [1] & $\mathrm{F}$ & Unknown & 26 & $\begin{array}{l}\text { Chest pain, } \\
\text { history of } \\
\text { pleurisy, } \\
\text { dyspnea }\end{array}$ & $\begin{array}{l}\text { Pleural thickening, } \\
\text { reticulations }\end{array}$ & $\begin{array}{l}\text { FVC } 41 \% \\
\text { TLC 68\%, } \\
\text { DLCO 34\% }\end{array}$ & $\begin{array}{l}\text { CS + AZA + MMF + } \\
\text { RTX (dose unknown) }\end{array}$ & Improvement \\
\hline [3] & $\mathrm{F}$ & 36 & 46 & $\begin{array}{l}\text { Dyspnea on } \\
\text { exertion, } \\
\text { orthopnea, } \\
\text { pleuritic } \\
\text { chest pain }\end{array}$ & $\begin{array}{l}\text { Elevated diaphragms, } \\
\text { atelectasis, pleural } \\
\text { thickening }\end{array}$ & FVC 77\%, TLC 68\% & $\begin{array}{l}\mathrm{CS}+\mathrm{CYC}+\mathrm{RTX}(375 \\
\mathrm{mg} / \mathrm{m} 2 \text { once weekly } \\
\times 4 \mathrm{q} 6 \mathrm{mo})\end{array}$ & $\begin{array}{l}\text { Asymptomatic, normal } \\
\text { PFTs }\end{array}$ \\
\hline [4] & $\mathrm{F}$ & 28 & $\begin{array}{l}28 \text { ( } 6 \text { mo } \\
\text { after } \\
\text { diagnosis } \\
\text { of SLE) }\end{array}$ & $\begin{array}{l}\text { Dyspnea, } \\
\text { pleuritic } \\
\text { chest pain, } \\
\text { dry cough, } \\
\text { orthopnea }\end{array}$ & Elevated diaphragms & FVC 61\%, TLC 45\% & $\begin{array}{l}\text { Beta-agonists }+ \\
\text { theophylline, RTX }(1 \\
\mathrm{g} \times 2 \text {, } 2 \text { weeks } \\
\text { apart }+ \text { CYC }\end{array}$ & $\begin{array}{l}\text { Asymptomatic, normal } \\
\text { PFTs }\end{array}$ \\
\hline [6] & $\mathrm{F}$ & 38 & $38^{\mathrm{a}}$ & $\begin{array}{l}\text { Tachypnea, } \\
\text { dyspnea }\end{array}$ & $\begin{array}{l}\text { Normal HRCT, } \\
\text { elevated diaphragms }\end{array}$ & FVC 64\%, FEV1 73\% & $\begin{array}{l}\text { CS + CYC without } \\
\text { improvement; } \\
\text { followed by RTX ( } 1 \\
g \times 2,2 \text { weeks apart) }\end{array}$ & $\begin{array}{l}\text { Normal PFTs, normal CXR } \\
6 \text { months after treatment }\end{array}$ \\
\hline [7] & $\mathrm{F}$ & 11 & 14 & $\begin{array}{l}\text { Dyspnea on } \\
\text { exertion, } \\
\text { chest pain }\end{array}$ & $\begin{array}{l}\text { Low lung volumes, } \\
\text { small bilateral pleural } \\
\text { effusions, small } \\
\text { pericardial effusion, } \\
\text { mild bibasilar } \\
\text { atelectasis }\end{array}$ & $\begin{array}{l}\text { FVC 31\%, TLC 32\%, } \\
\text { DLCO 96\% }\end{array}$ & $\begin{array}{l}\text { CYC monthly } \times 1 \text { year, } \\
\text { then RTX (dose } \\
\text { unknown) }\end{array}$ & $\begin{array}{l}\text { Clinical improvement, } \\
\text { PFTs } 2 \text { yrs. post: FVC } 82 \% \text {, } \\
\text { TLC } 80 \%\end{array}$ \\
\hline [14] & $\mathrm{F}$ & 22 & 27 & $\begin{array}{l}\text { Pleuritic } \\
\text { chest pain, } \\
\text { exertional } \\
\text { dyspnea }\end{array}$ & $\begin{array}{l}\text { Elevated diaphragms, } \\
\text { normal HRCT }\end{array}$ & $\begin{array}{l}\text { FVC } 1.45 \mathrm{~L} \text { (predicted } \\
\text { value } 4.20 \text { ), TLC } 2.35 \\
\text { (predicted value 5.76), } \\
\text { DLCO 16.3 (predicted } \\
\text { value 26.5) }\end{array}$ & $\begin{array}{l}\mathrm{CS}+\mathrm{RTX}(375 \mathrm{mg} / \mathrm{m} 2 \\
\times 2 \text { doses } 6 \text { weeks } \\
\text { apart })\end{array}$ & $\begin{array}{l}\text { Initial clinical improvement, } \\
\text { followed by re- } \\
\text { presentation requiring sec- } \\
\text { ond course of RTX. Im- } \\
\text { provement reported } 2 \text { yrs. } \\
\text { later }\end{array}$ \\
\hline [15] & $\mathrm{F}$ & 22 & 57 & $\begin{array}{l}\text { Dyspnea, dry } \\
\text { cough, } \\
\text { pleuritic } \\
\text { chest pain }\end{array}$ & $\begin{array}{l}\text { Elevated diaphragms, } \\
\text { bibasilar atelectasis }\end{array}$ & $\begin{array}{l}\text { FVC 43\%, TLC 56\%, } \\
\text { DLCO 55\% }\end{array}$ & $\begin{array}{l}\text { CS + beta-agonists + } \\
\text { AZA + MMF, then } 6 \\
\text { mo later RTX }(1 \mathrm{~g} \times 2 \\
\text { doses, } 2 \text { weeks apart, } \\
\text { repeated q6mo })\end{array}$ & $\begin{array}{l}\text { Clinical improvement. PFTs } \\
5 \text { years post: FVC } 76 \% \text {, TLC } \\
79 \% \text {, DLCO } 53 \%\end{array}$ \\
\hline [16] & $\mathrm{F}$ & Unknown & 28 & $\begin{array}{l}\text { Exercise } \\
\text { intolerance, } \\
\text { pleuritic } \\
\text { chest pain }\end{array}$ & Unknown & FVC $0.99 \mathrm{~L}$ & $\begin{array}{l}\mathrm{CS}+\mathrm{MMF}+\mathrm{RTX} \\
(2800 \mathrm{mg})\end{array}$ & $\begin{array}{l}\text { Unlimited exercise } \\
\text { tolerance, FVC } 2.23 \mathrm{~L}\end{array}$ \\
\hline [12] & $\mathrm{F}$ & 12 & 14 & $\begin{array}{l}\text { Dyspnea, } \\
\text { pleuritic } \\
\text { chest pain, } \\
\text { orthopnea }\end{array}$ & $\begin{array}{l}\text { Elevated right } \\
\text { hemidiaphragm }\end{array}$ & $\begin{array}{l}\text { FVC 36\%, TLC 39\%, } \\
\text { DLCO } 102 \%\end{array}$ & $\begin{array}{l}\text { CS + RTX (dose } \\
\text { unknown) + CYC }\end{array}$ & Active disease \\
\hline [8] & $\mathrm{F}$ & 36 & 37 & $\begin{array}{l}\text { Dyspnea, } \\
\text { pleuritic } \\
\text { chest pain }\end{array}$ & $\begin{array}{l}\text { CXR: Bilateral } \\
\text { diaphragmatic } \\
\text { elevation with mild } \\
\text { pleural effusion } \\
\text { HRCT: Mild pleural } \\
\text { effusion }\end{array}$ & Restrictive pattern & $\begin{array}{l}\mathrm{CS}+\mathrm{MTX}+\text { beta- } \\
\text { agonists + RTX (dose } \\
\text { unknown) }\end{array}$ & $\begin{array}{l}\text { Restrictive defect } \\
\text { improvement }\end{array}$ \\
\hline [8] & $\mathrm{F}$ & 36 & 39 & $\begin{array}{l}\text { Dyspnea, } \\
\text { pleuritic } \\
\text { chest pain, } \\
\text { fever }\end{array}$ & $\begin{array}{l}\text { CXR: Unilateral } \\
\text { diaphragmatic } \\
\text { elevation, left } \\
\text { atelectasia } \\
\text { HRCT: Basal atelectasis }\end{array}$ & Restrictive pattern & $\begin{array}{l}\text { CS + MMF + beta- } \\
\text { agonists + RTX (dose } \\
\text { unknown) }\end{array}$ & $\begin{array}{l}\text { Restrictive defect } \\
\text { stabilization. Developed } \\
\text { ILD } 4 \text { yrs. later }\end{array}$ \\
\hline [8] & $\mathrm{F}$ & 27 & 31 & $\begin{array}{l}\text { Dyspnea, } \\
\text { pleuritic } \\
\text { chest pain }\end{array}$ & $\begin{array}{l}\text { CXR: Unilateral } \\
\text { diaphragmatic } \\
\text { elevation, right } \\
\text { atelectasia } \\
\text { HRCT: Basal atelectasis, }\end{array}$ & Restrictive pattern & $\begin{array}{l}\text { CS + theophylline + } \\
\text { beta-agonists }+ \text { RTX } \\
\text { (dose unknown) }\end{array}$ & $\begin{array}{l}\text { Restrictive defect } \\
\text { stabilization }\end{array}$ \\
\hline
\end{tabular}


Table 1 Clinical features, treatment and outcome of patients with SLS associated with SLE who received treatment with rituximab (Continued)

\begin{tabular}{|c|c|c|c|c|c|c|c|c|}
\hline Reference & Sex & $\begin{array}{l}\text { Age at } \\
\text { SLE } \\
\text { diagnosis }\end{array}$ & $\begin{array}{l}\text { Age at } \\
\text { SLS } \\
\text { diagnosis }\end{array}$ & $\begin{array}{l}\text { Clinical } \\
\text { presentation }\end{array}$ & $\begin{array}{l}\text { Imaging findings at } \\
\text { SLS diagnosis }\end{array}$ & $\begin{array}{l}\text { PFTs at SLS } \\
\text { diagnosis }\end{array}$ & Treatment & Outcome \\
\hline & & & & & mild pleural effusion & & & \\
\hline [8] & $\mathrm{F}$ & 23 & 30 & $\begin{array}{l}\text { Dyspnea, } \\
\text { pleuritic } \\
\text { chest pain }\end{array}$ & $\begin{array}{l}\text { CXR: Unilateral } \\
\text { diaphragmatic } \\
\text { elevation } \\
\text { HRCT: Basal atelectasis }\end{array}$ & Restrictive pattern & $\begin{array}{l}\mathrm{CS}+\mathrm{MMF}+\text { beta- } \\
\text { agonists + RTX (dose } \\
\text { unknown) }\end{array}$ & $\begin{array}{l}\text { Restrictive defect } \\
\text { improvement }\end{array}$ \\
\hline [8] & $\mathrm{F}$ & 34 & 59 & $\begin{array}{l}\text { Dyspnea, } \\
\text { pleuritic } \\
\text { chest pain }\end{array}$ & $\begin{array}{l}\text { CXR: Bilateral } \\
\text { diaphragmatic } \\
\text { elevation, atelectasia } \\
\text { HRCT: Basal atelectasis }\end{array}$ & Restrictive pattern & $\begin{array}{l}C S+M M F+R T X \text { (dose } \\
\text { unknown) + IVIG }\end{array}$ & $\begin{array}{l}\text { Restrictive defect } \\
\text { stabilization }\end{array}$ \\
\hline
\end{tabular}

CS corticosteroids, RTX rituximab, CYC cyclophosphamide, AZA azathioprine, MMF mycophenolate mofetil, IVIG intravenous immunoglobulin, CXR chest X-ray, HRCT high-resolution computed tomography, PFTs pulmonary function tests, FEV1 forced expiratory volume in $1 \mathrm{~s}$, FVC forced vital capacity, TLC total lung capacity, DLCO diffusing capacity for carbon monoxide, ILD interstitial lung disease. PFT results expressed in \% predicted when available ${ }^{a}$ Diagnosis of SLS made at the time of diagnosis of SLE

patients $16-18$ years of age have been reported, most in case series of SLS, however very limited information was given on their disease course [1, 5, 12, 21, 22].

Although extremely rare, it is important to recognize SLS as a possible cause of dyspnea and chest pain in a child with SLE, and be aware that in pediatric patients in particular, this complication may occur at the time of initial presentation of SLE. Our patient clearly stated that his goal for treatment was to return to competitive hockey. Recent literature on rituximab use in SLS, a review of pediatric SLS cases, and our case report suggest that additional therapy, including possible use of

Table 2 Clinical features, treatment, and outcome of reported pediatric cases of SLS associated with SLE

\begin{tabular}{|c|c|c|c|c|c|c|c|c|}
\hline Reference & Sex & $\begin{array}{l}\text { Age at } \\
\text { SLE } \\
\text { diagnosis }\end{array}$ & $\begin{array}{l}\text { Age at } \\
\text { SLS } \\
\text { diagnosis }\end{array}$ & Clinical presentation & $\begin{array}{l}\text { Imaging findings at SLS } \\
\text { diagnosis }\end{array}$ & $\begin{array}{l}\text { PFTs at } \\
\text { SLS } \\
\text { diagnosis }\end{array}$ & Treatment & Outcome \\
\hline$[2]$ & $\mathrm{F}$ & 12 & $12^{a}$ & $\begin{array}{l}\text { Prior diagnosis of } \\
\text { mycoplasma } \\
\text { pneumonia with } \\
\text { recovery. Re-presented } \\
6 \text { months later with } \\
\text { dyspnea }\end{array}$ & $\begin{array}{l}\text { CXR: Enlarged cardiac } \\
\text { silhouette, low lung } \\
\text { volumes, elevated } \\
\text { diaphragms } \\
\text { HRCT: thoracic } \\
\text { lymphadenopathy }\end{array}$ & $\begin{array}{l}\text { FEV1 34\%, } \\
\text { FVC 27\%, } \\
\text { TLC 59\% }\end{array}$ & $\begin{array}{l}C S+C Y C \\
(q 4 \text { weeks } \times \\
6 \mathrm{mo})\end{array}$ & $\begin{array}{l}\text { Asymptomatic. Normal } \\
\text { PFTs after } 1 \text { yr (FEV1 99\%, } \\
\text { FVC 97\%, TLC 92\%) }\end{array}$ \\
\hline$[7]$ & $\mathrm{F}$ & 11 & 14 & $\begin{array}{l}\text { Dyspnea on exertion, } \\
\text { chest pain }\end{array}$ & $\begin{array}{l}\text { CXR: Low lung volumes, } \\
\text { small pleural effusions, small } \\
\text { pericardial effusion, mild } \\
\text { bibasilar atelectasis }\end{array}$ & $\begin{array}{l}\text { FVC 31\%, } \\
\text { TLC 32\%, } \\
\text { DLCO } \\
96 \%\end{array}$ & $\begin{array}{l}\text { CYC } \\
\text { monthly } \times \\
1 \text { year, then } \\
\text { RTX (dose } \\
\text { unknown) }\end{array}$ & $\begin{array}{l}\text { Clinical improvement, } \\
\text { PFTs } 2 \text { yrs. post: FVC 82\%, } \\
\text { TLC } 80 \%\end{array}$ \\
\hline [10] & $\mathrm{F}$ & 15 & $15^{\mathrm{a}}$ & $\begin{array}{l}\text { Pleuritic chest pain, dry } \\
\text { cough, dyspnea on } \\
\text { exertion }\end{array}$ & $\begin{array}{l}\text { Small lung fields, elevated } \\
\text { bilateral hemidiaphragms, } \\
\text { chest CT normal }\end{array}$ & $\begin{array}{l}\text { FEV1 26\%, } \\
\text { FVC 25\%, } \\
\text { TLC 31\% }\end{array}$ & Beta-agonist & $\begin{array}{l}\text { Clinical improvement. } \\
\text { PFTs after } 12 \mathrm{~d} \text { showed } \\
\text { FEV1 increase of } 58 \% \text {, } \\
\text { FVC increase of } 50 \% \text {, TLC } \\
\text { increase of } 47 \%\end{array}$ \\
\hline$[17]$ & M & 11 & 14 & $\begin{array}{l}\text { Fatigue, dyspnea, } \\
\text { pleuritic chest pain }\end{array}$ & $\begin{array}{l}\text { Enlarged cardiac silhouette, } \\
\text { atelectasis, severely reduced } \\
\text { diaphragmatic excursion on } \\
\text { fluoroscopy }\end{array}$ & $\begin{array}{l}\text { FEV1 23\%, } \\
\text { FVC 20\%, } \\
\text { TLC 34\% }\end{array}$ & $C S+A Z A$ & $\begin{array}{l}\text { Follow-up } 23 \text { days later: } \\
\text { FEV1 45\%, FVC 45\%, TLC } \\
57 \%\end{array}$ \\
\hline$[18]$ & $\mathrm{F}$ & 12 & $12^{a}$ & $\begin{array}{l}\text { Pleuritic chest pain, } \\
\text { dyspnea, fever, fatigue, } \\
\text { anorexia }\end{array}$ & $\begin{array}{l}\text { CXR: Reduced lung volumes, } \\
\text { elevated diaphragms, HRCT: } \\
\text { pleural thickening } \\
\text { Diaphragmatic fluoroscopy: } \\
\text { minimal movement }\end{array}$ & $\begin{array}{l}\text { FVC 39\%, } \\
\text { TLC 60\%, } \\
\text { DLCO } \\
\text { normal }\end{array}$ & $\mathrm{CS}+\mathrm{HCQ}$ & $\begin{array}{l}4 \text { yrs. post: ongoing } \\
\text { activity limitation, PFTs } \\
\text { unchanged }\end{array}$ \\
\hline$[12]$ & $\mathrm{F}$ & 12 & 14 & $\begin{array}{l}\text { Dyspnea, pleuritic } \\
\text { chest pain, orthopnea }\end{array}$ & $\begin{array}{l}\text { Elevated right } \\
\text { hemidiaphragm }\end{array}$ & $\begin{array}{l}\text { FVC 36\%, } \\
\text { TLC 39\%, } \\
\text { DLCO } \\
102 \%\end{array}$ & $\begin{array}{l}\text { CS }+ \text { RTX } \\
\text { (dose } \\
\text { unknown)+ } \\
\text { CYC }\end{array}$ & Active disease \\
\hline
\end{tabular}

CS corticosteroids, RTX rituximab, CYC cyclophosphamide, $A Z A$ azathioprine, $H C Q$ hydroxychloroquine, $C X R$ chest X-ray, $H R C T$ high-resolution computed tomography, PFTs pulmonary function tests, FEV 1 forced expiratory volume in $1 \mathrm{~s}$, FVC forced vital capacity, TLC total lung capacity, DLCO diffusing capacity for carbon monoxide. PFT results expressed in \% predicted when available

${ }^{a}$ Diagnosis of SLS made at the time of diagnosis of SLE 
rituximab, should be considered in patients with SLS who have an incomplete response to initial immunosuppressive therapy. Careful documentation of the occurrence, treatment and outcome of patients with SLS utilizing large registries of adult and pediatric patients with SLE may help determine optimal treatment for this rare complication.

\section{Abbreviations}

SLS: Shrinking lung syndrome; SLE: Systemic lupus erythematosus; PFT: Pulmonary function test; FEV1: Forced expiratory volume in $1 \mathrm{~s}$; FVC: Forced vital capacity; TLC: Total lung capacity; RV: Residual volume; RSV: Respiratory syncytial virus; CXR: Chest x ray; dsDNA: Double stranded DNA; ANA: Antinuclear antibody; IVMP: Methylprednisolone; PCR: Polymerase chain reaction; HRCT: High resolution computed tomography

\section{Acknowledgements}

We thank the patient and family for participating in this report.

\section{Authors' contributions}

$C D$ and $B L$ reviewed the patient's medical record pertaining to this case and were major contributors in writing the manuscript. All authors read and approved the final manuscript.

\section{Funding}

None.

\section{Availability of data and materials}

Data sharing is not applicable to this article as no datasets were generated or analyzed during the current study.

\section{Ethics approval and consent to participate}

Research Ethics Board approval (\#1024379) was obtained from the IWK Health Centre. Written and informed consent was also obtained from the patient.

\section{Consent for publication}

Written and informed consent was obtained from the patient to publish this material.

\section{Competing interests}

The authors declare that they have no competing interests.

Received: 18 March 2020 Accepted: 9 December 2020

Published online: 06 January 2021

\section{References}

1. Duron L, Cohen-Aubart F, Diot E, Borie R, Abad S, Richez C, et al. Shrinking lung syndrome associated with systemic lupus erythematosus: a multicenter collaborative study of 15 new cases and a review of the 155 cases in the literature focusing on treatment response and long-term outcomes. Autoimmun Rev. 2016;15:994-1000.

2. Meinicke $H_{1}$ Heinzmann $A$, Geiger J, Berner $R$, Hufnagel M. Symptoms of shrinking lung syndrome reveal systemic lupus erythematosus in a 12-yearold girl. Pediatr Pulmonol. 2013:48:1246-9.

3. Toya SP, Tzelepis GE. Association of the shrinking lung syndrome in systemic lupus erythematosus with pleurisy: a systematic review. Semin Arthritis Rheum. 2008:39:30-7.

4. Langenskiold E, Bonetti A, Fitting JW, Heinzer R, Dudler J, Spertini F, et al. Shrinking lung syndrome successfully treated with rituximab and cyclophosphamide. Respiration. 2012;84:144-9.

5. Deeb M, Tselios K, Gladman DD, Su J, Urowitz MB. Shrinking lung syndrome in systemic lupus erythematosus: a single-centre experience. Lupus. 2018;27: 365-71.

6. Goswami RP, Mondal S, Lahiri D, Basu K, Das S, Ghosh P, et al. Shrinking lung syndrome in systemic lupus erythematosus successfully treated with rituximab. QJM-INT J Med. 2016;109:617-8

7. Burns NS, Stevens AM, lyer RS. Shrinking lung syndrome complicating pediatric systemic lupus erythematosus. Pediatr Radiol. 2014;44:1318-22.
8. Borrell H, Narvaez J, Alegre JJ, Castellvi I, Mitjavila F, Aparicio M, Armengol E, Molina-Molina M, Nolla JM. Shrinking lung syndrome in systemic lupus erythematosus: a case series and review of the literature. Medicine. 2016; 95(33):e4626.

9. Hoffbrand BI, Beck ER. "Unexplained" dyspnoea and shrinking lungs in systemic lupus erythematosus. Br Med J. 1965;1:1273-7.

10. Thompson PJ, Dhillon DP, Ledingham J, Turner-Warwick M. Shrinking lungs, diaphragmatic dysfunction, and systemic lupus erythematosus. Am Rev Respir Dis. 1985;132(4):926-8.

11. Ciaffi J, Gegenava M, Ninaber M, Huizinga TW. Shrinking lung syndrome: diagnostic and therapeutic challenges in 3 patients with systemic lupus erythematosus. J Clin Rheumatol. 2019. https://doi.org/10.1097/RHU. 0000000000001132.

12. Henderson L, Loring S, Gill R, Liao K, Ishizawar R, Kim S, PerimutterGoldenson R, Rothman D, Son MB, Stoll M, Zemel L, Sandborg C, Dellaripa $P$, Nigrovic $P$. Shrinking lung syndrome as a manifestation of pleuritis: a new model based on pulmonary physiologic studies. J Rheumatol. 2013;40(3): 273-81.

13. Hannah JR, D'Cruz DP. Pulmonary complications of systemic lupus erythematosus. Semin Respir Crit Care Med. 2019;40:227-34.

14. Benham H, Garske L, Vecchio P, Eckert BW. Successful treatment of shrinking lung syndrome with rituximab in a patient with systemic lupus erythematosus. J Clin Rheumatol. 2010;16:68-70

15. Penacoba Toribio P, Córica Albani ME, Mayos Pérez M, Rodríguez de la Serna A. Rituximab in the treatment of shrinking lung syndrome in systemic lupus erythematosus. Reumatol Clin. 2014;10:325-7.

16. Butterly SJ, Pillans P, Horn B, Miles R, Sturtevant J. Off-label use of rituximab in a tertiary Queensland hospital. Intern Med J. 2010:40:443-52.

17. Ferguson PJ, Weinburger M. Shrinking lung syndrome in a 14-year-old boy with systemic lupus erythematosus. Pediatr Pulmonol. 2006:41(2):194-7.

18. Krych EH, Fischer PR, Wylam ME. Pleural fibrosis mediates shrinking lungs syndrome in children. Pediatr Pulmonol. 2009;44:90-2.

19. Calderaro DC, Ferreira GA. Presentation and prognosis of shrinking lung syndrome in systemic lupus erythematosus: report of four cases. Rheumatol Int. 2012;32:1391-6.

20. Karim MY, Miranda LC, Tench CM, Gordon PA, D'cruz DP, Khamashta MA, Hughes GR. Presentation and prognosis of the shrinking lung syndrome in systemic lupus erythematosus. Semin Arthritis Rheum. 2002;31(5):289-98.

21. LaRoche CM, Mulvey DA, Hawkins PN, Walport MJ, Strickland B, Moxham J, Green M. Diaphragm strength in the shrinking lung syndrome of systemic lupus erythematosus. Q J Med. 1989;71(265):429-39.

22. Pillai S, Mehta J, Levin T, Muzumdar H, Nandalike K. Shrinking lung syndrome presenting as an initial pulmonary manifestation of SLE. Lupus. 2014:23(11):1201-3.

\section{Publisher's Note}

Springer Nature remains neutral with regard to jurisdictional claims in published maps and institutional affiliations.

Ready to submit your research? Choose BMC and benefit from:

- fast, convenient online submission

- thorough peer review by experienced researchers in your field

- rapid publication on acceptance

- support for research data, including large and complex data types

- gold Open Access which fosters wider collaboration and increased citations

- maximum visibility for your research: over $100 \mathrm{M}$ website views per year

At BMC, research is always in progress.

Learn more biomedcentral.com/submission 